\title{
HPV, protein p16 and squamous cell carcinoma of the oral cavity
}

\author{
Jiri Blahak', Jiri Zelinka ${ }^{\mathrm{a}}$, Jaromir Gumulec ${ }^{\text {, Ctirad Machacek }}{ }^{\mathrm{b}}$, Zdenek Danek ${ }^{\mathrm{a}}$, Oliver Bulik ${ }^{\mathrm{a}}$
}

\begin{abstract}
Background. Squamous cell carcinoma of the oral cavity is generally caused by the long-term impact of known risk factors, e.g. tobacco and alcohol, along with chronic traumatisation. A number of studies now implicate HPV infection in head and neck tumour carcinogenesis but the exact role of HPV infection in the oral cavity remains unclear.

Methods. In this study, we evaluated 78 patients with oral squamous cell carcinoma (OSCC) for the expression of protein p16 in the context of HPV positivity and its influence on the overall survival rate, disease location, staging and grading. Results. Regarding the tumour location, no significant difference was found between HPV-positive and HPV-negative patients, nor between p16-positive and p16-negative patients. There was also no trend in terms of HPV status and stage, and differentiation of carcinoma. There was no effect on HPV-positive patients relative to the time to progression $(P=0.84)$ and overall survival rate $(P=0.78)$. $P 16$ positivity was not found to have an effect on the overall survival rate of patients $(P=0.41)$ and there was no correlation between $\mathrm{p} 16$ positivity relative to the time to progression $(P=0.66)$.

Conclusions. In summary, the data suggest that there is no effect of HPV status on the prognosis of OSCC patients compared to other HNSCC locations.
\end{abstract}

Key words: oral squamous cell carcinoma, oral cancer, HPV, human papilloma virus, p16

Received: February 24, 2019; Revised: May 15, 2019; Accepted: May 28, 2019; Available online: June 17, 2019 https://doi.org/10.5507/bp.2019.026

(c) 2020 The Authors; https://creativecommons.org/licenses/by/4.0/

${ }^{a}$ Department of Oral and Maxillofacial Surgery, Faculty of Medicine, Masaryk University, Brno and University Hospital Brno, Brno, Czech Republic

${ }^{b}$ Department of Pathology, Faculty of Medicine, Masaryk University, Brno and University Hospital Brno, Brno, Czech Republic 'Department of Pathological Physiology, Faculty of Medicine, Masaryk University, Brno, Czech Republic Corresponding author: Jiri Blahak, e-mail:jiriblahak@gmail.com

\section{INTRODUCTION}

In 2012, oral cavity tumours were diagnosed in over 300,000 patients worldwide, of which 60,000 were diagnosed in Europe. The most frequent malignant carcinoma of the oral cavity is (OSCC) (ref. $\left.{ }^{1}\right)$. In oral squamous cell carcinoma the Czech Republic, the incidence of OSCC affects 4.82/100,000 individuals with a 2.12/100,000 mortality rate and occurs more often in $\mathrm{men}^{2}$. Unfortunately, most patients come to the doctor with the advanced form - clinical stage IV - which is observed in $43 \%$ of these cases. Lately, there has been a changing tendency observed in head and neck squamous cell carcinomas (HNSCC), especially in oropharyngeal carcinomas (OPSCC): HPVpositive oropharyngeal tumours clinically and molecularly differ from HPV-negative tumours, and can be associated with varied prognostic results ${ }^{3,4}$. HPV-positive HNSCCs display different risk factors than HPV-negative cancers, and are more likely to be differentiated from those caused by tobacco and alcohol ${ }^{5,6}$.

HPVs are small non-enveloped double-stranded DNA viruses that belong to the Papillomaviridae family, a large group of viruses with new types that are continuously being identified ${ }^{7}$. HPVs cause a wide range of diseases, from benign lesions to invasive tumours ${ }^{8,9}$.

Currently, the highest designated HPV-type number is HPV 225 (www.hpvcenter.se, accessed on 2018-04-15).
The most common, HR HPV type 16, is found in more than $95 \%$ of HPV positive HNSCC tumours ${ }^{10,11}$. High-risk types of HPV encode two viral oncoproteins, E6 and E7, that promote tumour progression by inactivating the TP53 and retinoblastoma tumour suppressor gene products ${ }^{5}$.

Protein p16 is a cyclin-dependent kinase inhibitor that inhibits $\mathrm{pRb}$ phosphorylation and blocks cell cycle progression at the $\mathrm{G} 1$ to $\mathrm{S}$ check point ${ }^{12}$. The loss of $\mathrm{p} 16 \mathrm{ex}-$ pression results in a worse prognosis for HNSCC (ref. $\left.{ }^{13}\right)$. The overexpression of protein $\mathrm{p} 16$ ( $\mathrm{p} 16$ - positive) has been correlated with an improved outcome in OPSCC and possibly in OSCC (ref. ${ }^{14}$ ). The expression of p16 occurs as a result of the functional inactivation of the retinoblastoma protein $(\mathrm{pRb})$ by the HPV E7 protein ${ }^{15}$. This leads to the up-regulation of protein $\mathrm{p} 16$. Thus, HPV positive tumours are characterized by the high expression of protein $\mathrm{p} 16\left(\right.$ ref. $\left.^{16}\right)$. This is typical in head and neck tumours for OPSCC (ref. ${ }^{17}$ ), but for tumours of the oral cavity it is necessary to further explore this question. On the other hand, the down-regulation of $\mathrm{p} 16$ appears to be associated with HPV-negative (tobacco, alcohol) HNSCC $\left(\right.$ ref. ${ }^{18}$ ).

The goal of this study was to evaluate the expression of protein p16 in the context of HPV positivity and to evaluate the overall survival rate in HPV and p16-positive patients with oral cavity tumours, which has not been frequently studied, particularly in regards to HPV status. 
Table 1. Baseline characteristics of the study patients and their tumors.

\begin{tabular}{|c|c|c|c|c|c|c|c|}
\hline Factor & median (IQR) & $\mathrm{HPV}+$ & HPV - & $\mathrm{HPV} \mathrm{n/s}$ & $\mathrm{p} 16+$ & p16- & $\mathrm{p} 16 \mathrm{n} / \mathrm{s}$ \\
\hline Age & $59.64(52.29$ to 66.87$)$ & & & & & & \\
\hline \multicolumn{8}{|l|}{ Sex } \\
\hline M & $59(75 \%)$ & $5(6 \%)$ & $50(63 \%)$ & $4(5 \%)$ & $5(6 \%)$ & $50(63 \%)$ & $4(5 \%)$ \\
\hline $\mathrm{F}$ & $19(24 \%)$ & $1(1 \%)$ & $18(23 \%)$ & $0(0 \%)$ & $2(3 \%)$ & $16(20 \%)$ & $1(1 \%)$ \\
\hline \multicolumn{8}{|l|}{ Primary site } \\
\hline tongue - the front two-thirds & $12(15 \%)$ & $2(3 \%)$ & $10(13 \%)$ & $0(0 \%)$ & $1(1 \%)$ & $9(11 \%)$ & $2(3 \%)$ \\
\hline base of the tongue & $7(9 \%)$ & $0(0 \%)$ & $7(9 \%)$ & $1(1 \%)$ & $0(0 \%)$ & $7(9 \%)$ & $0(0 \%)$ \\
\hline floor of the mouth - frontal area & $21(27 \%)$ & $1(1 \%)$ & $20(25 \%)$ & $2(3 \%)$ & $3(4 \%)$ & $18(23 \%)$ & $0(0 \%)$ \\
\hline floor of the mouth - distal area & $14(18 \%)$ & $1(1 \%)$ & $13(16 \%)$ & $0(0 \%)$ & $1(1 \%)$ & $12(15 \%)$ & $1(1 \%)$ \\
\hline mandibulary alveolar ridge & $12(15 \%)$ & $1(1 \%)$ & $11(14 \%)$ & $1(1 \%)$ & $0(0 \%)$ & $10(13 \%)$ & $2(3 \%)$ \\
\hline retromolar trigone & $3(4 \%)$ & $0(0 \%)$ & $3(4 \%)$ & $0(0 \%)$ & $0(0 \%)$ & $3(4 \%)$ & $0(0 \%)$ \\
\hline maxillary alveolar ridge & $4(5 \%)$ & $1(1 \%)$ & $3(4 \%)$ & $0(0 \%)$ & $1(1 \%)$ & $3(4 \%)$ & $0(0 \%)$ \\
\hline cheek & $5(6 \%)$ & $0(0 \%)$ & $5(6 \%)$ & $0(0 \%)$ & $1(1 \%)$ & $4(5 \%)$ & $0(0 \%)$ \\
\hline \multicolumn{8}{|l|}{ Clinical stage } \\
\hline I & $6(8 \%)$ & $1(1 \%)$ & $5(6 \%)$ & $0(0 \%)$ & $0(0 \%)$ & $5(6 \%)$ & $1(1 \%)$ \\
\hline II & $15(19 \%)$ & $0(0 \%)$ & $15(19 \%)$ & $1(1 \%)$ & $1(1 \%)$ & $12(15 \%)$ & $2(3 \%)$ \\
\hline III & $16(20 \%)$ & $3(4 \%)$ & $13(16 \%)$ & $1(1 \%)$ & $2(3 \%)$ & $13(16 \%)$ & $1(1 \%)$ \\
\hline IVa & $34(43 \%)$ & $2(3 \%)$ & $30(38 \%)$ & $2(3 \%)$ & $4(5 \%)$ & $29(37 \%)$ & $1(1 \%)$ \\
\hline $\mathrm{IVb}$ & $7(9 \%)$ & $0(0 \%)$ & $7(9 \%)$ & $0(0 \%)$ & $0(0 \%)$ & $7(9 \%)$ & $0(0 \%)$ \\
\hline \multicolumn{8}{|l|}{ Tumour stage “T” } \\
\hline $\mathrm{T} 1$ & $6(8 \%)$ & $1(1 \%)$ & $5(6 \%)$ & $0(0 \%)$ & $0(0 \%)$ & $5(6 \%)$ & $1(1 \%)$ \\
\hline $\mathrm{T} 2$ & $27(34 \%)$ & $2(3 \%)$ & $24(30 \%)$ & $1(1 \%)$ & $1(1 \%)$ & $20(25 \%)$ & $2(3 \%)$ \\
\hline $\mathrm{T} 3$ & $19(24 \%)$ & $2(3 \%)$ & $17(22 \%)$ & $1(1 \%)$ & $2(3 \%)$ & $17(22 \%)$ & $1(1 \%)$ \\
\hline $\mathrm{T} 4$ & $26(33 \%)$ & $2(3 \%)$ & $22(28 \%)$ & $2(3 \%)$ & $4(5 \%)$ & $24(30 \%)$ & $1(1 \%)$ \\
\hline \multicolumn{8}{|l|}{ Nodal stage "N" } \\
\hline N0 & $34(43 \%)$ & $2(3 \%)$ & $30(38 \%)$ & $2(3 \%)$ & $3(4 \%)$ & $27(34 \%)$ & $4(5 \%)$ \\
\hline N1 & $15(19 \%)$ & $3(4 \%)$ & $11(14 \%)$ & $1(1 \%)$ & $1(1 \%)$ & $13(16 \%)$ & $1(1 \%)$ \\
\hline $\mathrm{N} 2 \mathrm{a}$ & $1(1 \%)$ & $0(0 \%)$ & $1(1 \%)$ & $0(0 \%)$ & $1(1 \%)$ & $0(0 \%)$ & $0(0 \%)$ \\
\hline $\mathrm{N} 2 \mathrm{~b}$ & $17(22 \%)$ & $1(1 \%)$ & $15(19 \%)$ & $1(1 \%)$ & $1(1 \%)$ & $16(20 \%)$ & $0(0 \%)$ \\
\hline $\mathrm{N} 2 \mathrm{c}$ & $11(14 \%)$ & $0(0 \%)$ & $11(14 \%)$ & $0(0 \%)$ & $1(1 \%)$ & $10(13 \%)$ & $0(0 \%)$ \\
\hline N3 & $0(0 \%)$ & $0(0 \%)$ & $0(0 \%)$ & $0(0 \%)$ & $0(0 \%)$ & $0(0 \%)$ & $0(0 \%)$ \\
\hline \multicolumn{8}{|l|}{ Distant metastases "M" } \\
\hline M0 & $75(95 \%)$ & $6(8 \%)$ & $65(82 \%)$ & $4(5 \%)$ & $7(9 \%)$ & $63(80 \%)$ & $5(6 \%)$ \\
\hline M1 & $3(4 \%)$ & $0(0 \%)$ & $3(4 \%)$ & $0(0 \%)$ & $0(0 \%)$ & $3(4 \%)$ & $0(0 \%)$ \\
\hline \multicolumn{8}{|l|}{ Grading } \\
\hline G1 & $24(30 \%)$ & $1(1 \%)$ & $21(27 \%)$ & $2(3 \%)$ & $(0 \%)$ & $(0 \%)$ & $(0 \%)$ \\
\hline G2 & $31(39 \%)$ & $2(3 \%)$ & $29(37 \%)$ & $0(0 \%)$ & $(0 \%)$ & $(0 \%)$ & $(0 \%)$ \\
\hline G3 & $13(16 \%)$ & $1(1 \%)$ & $10(13 \%)$ & $2(3 \%)$ & $(0 \%)$ & $(0 \%)$ & $(0 \%)$ \\
\hline G4 & $1(1 \%)$ & $0(0 \%)$ & $1(1 \%)$ & $0(0 \%)$ & $(0 \%)$ & $(0 \%)$ & $(0 \%)$ \\
\hline $\mathrm{N} / \mathrm{S}$ & $9(11 \%)$ & $2(3 \%)$ & $7(9 \%)$ & $0(0 \%)$ & $(0 \%)$ & $(0 \%)$ & $(0 \%)$ \\
\hline \multicolumn{8}{|l|}{ HPV status of primary tumour } \\
\hline negative & $68(86 \%)$ & - & - & - & $5(6 \%)$ & $58(73 \%)$ & $5(6 \%)$ \\
\hline Positive & $6(8 \%)$ & - & - & - & $2(3 \%)$ & $4(5 \%)$ & $0(0 \%)$ \\
\hline $\mathrm{N} / \mathrm{S}$ & $4(5 \%)$ & - & - & - & $0(0 \%)$ & $4(5 \%)$ & $0(0 \%)$ \\
\hline \multicolumn{8}{|l|}{ p16 Expression in primary tumour } \\
\hline negative & $66(84 \%)$ & $4(5 \%)$ & $58(73 \%)$ & $4(5 \%)$ & - & - & - \\
\hline Positive & $7(9 \%)$ & $2(3 \%)$ & $5(6 \%)$ & $0(0 \%)$ & - & - & - \\
\hline $\mathrm{N} / \mathrm{S}$ & $5(6 \%)$ & $0(0 \%)$ & $5(6 \%)$ & $0(0 \%)$ & - & - & - \\
\hline
\end{tabular}




\section{MATERIALS AND METHODS}

\section{Set of Patients}

The patients included in the study $(\mathrm{n}=78)$ were treated at the Department of Oral and Maxillofacial Surgery, University Hospital Brno, from January 2011 until December 2014. Inclusion criterion was the histopathological diagnosis of oral squamous cell carcinoma (OSCC) and tumour localization exclusively in oral cavities. The exclusion criteria were OSCC relapses and any additional locations other than the oral cavity and lips. Baseline characteristics of the study patients and their tumours is provided in Table 1 .

\section{$\mathrm{HPV}$ analysis}

DNA extracted from native tumour tissue was used for HPV typing analysis. HPV typing was performed at the Department of Microbiology, University Hospital Brno. INNO-LiPA research genotyping assay (Innogenetics, Gent, Belgium) was used for HPV typing.

The INNO-LiPA HPV Genotyping Extra is a line probe assay for in-vitro diagnostic use, designed for the identification of 28 different genotypes (6LR, 11LR, $16 \mathrm{HR}, 18 \mathrm{HR}, 26 \mathrm{pHR}$, 31HR, 33HR, 35HR, 39HR, 40LR, 43LR, 44LR, 45HR, 51HR, 52HR, 53pHR, 54LR, 56HR, 58HR, 59HR, 66pHR, 68HR, 69/71, 70LR, 73HR, 74, 82HR) of the human papillomavirus (HPV) by the detection of specific sequences in the L1 region of the HPV genome.

The results were interpreted either visually or by using LiRAS ${ }^{\circledR}$ for LiPA HPV software.

\section{p16 analysis}

In our study, archived, formalin-fixed, paraffin-embedded tissue samples with OSCC were analysed for protein p16 expression. Immunohistochemical analysis was performed at the Institute of Pathology, University Hospital Brno, with CINtec ${ }^{\circledR}$ p 16 Histology, Ventana. CINtec Histology is a qualitative test and the CINtec Histology status is interpreted as either positive or negative based on the p16 staining pattern in the squamous epithelium.

Tumour p16 expression was evaluated by means of immunohistochemical analysis with mouse monoclonal antibody Anti- p16INK4a (E6H4) against protein p16INK4a, in formalin-fixed, paraffin-embedded (FFPE) tissue samples.

Positive p16 expression was defined as strong, with diffuse nuclear and cytoplasmic staining in $70 \%$ or more of the tumour cells ${ }^{18-22}$. Figure 1 shows representative images of a $\mathrm{p} 16^{\mathrm{INK4a}}$-immunolabelled.

\section{Statistical analysis}

The categorical and continuous variables were analysed using the $\chi 2$ test or the Mann-Whitney U test, respectively. Survival-rate analysis was performed by the Kaplan-Meier approach followed by a log-rank test. The relationship between clinicopathological characteristics and a patient's outcome was determined in multivariate models using the Cox proportional hazard regression. The $P$ values of less than 0.05 were considered significant, unless noted otherwise. Analyses were performed at Statistica 12.2 (Dell, OK, USA)

\section{RESULTS}

\section{Patient characterization, p16 and HPV status}

Of the 78 patients with tumours, 35 tumours were located in the floor of the mouth (27\%), 21 in the frontal area, and 14 in the distal area. The second most common site was the tongue (12 at the apex, seven at the base) followed by the mandibular alveolar ridge (12 tumours), five in the cheek, four in the maxillary alveolar ridge and the final location was the retromolar trigone with three tumours.

Regarding the tumour locations, there was no significant difference detected between HPV-positive and HPVnegative patients $(P=0.79$, Pearson Chi-square)

Six out of the 78 patients ( $8 \%$ ) tested positive for HPV (Table 1). High-risk HPV viruses $16 / 31$ were present in three out of the six patients with HPV positivity. In one patient, we found pHR26, and in two patients, low-risk HPV 11 was found. Only one patient from the HPVpositive group was a woman (Table 2). No distant metastases were found; tumours were found in the tongue $(2 / 6)$, the floor of mouth $(2 / 6)$, the mandibular $(1 / 6)$ and the maxillary alveolus (1/6). All of the patients were treated by primary surgery, while five of those subsequently received adjuvant therapy. The group of patients included all clinical stages, the majority having stage III (3/6). At the end of a three-year evaluation, half of the patients were still living, while the other half had died due to complications from the tumour. In four patients, it was not possible to evaluate the HPV status.

As Table 1 shows, most patients were $\mathrm{p} 16$ negative $(n=66,84 \%)$, while seven patients $(9 \%)$ were $\mathrm{p} 16$ positive.

Table 2. Baseline characteristics of patients with HPV positive tumors.

\begin{tabular}{|c|c|c|c|c|c|c|c|c|c|c|}
\hline gender & age & localization & stage & & T N M & & grade & $\begin{array}{c}\text { HPV } \\
\text { genotype }\end{array}$ & $\begin{array}{l}\text { p16 positivity } \\
\text { ++/-" }\end{array}$ & $\begin{array}{c}\text { p16 positivity } \\
\text { "\%" }\end{array}$ \\
\hline $\mathrm{M}$ & 59 & tongue & III & $\mathrm{T} 2$ & N1 & M0 & 2 & LR 11 & + & 85 \\
\hline M & 62 & floor of mouth & III & T3 & N1 & M0 & 2 & HR 31 & - & 0 \\
\hline M & 56 & mandibular alveolus & IV & $\mathrm{T} 4$ & $\mathrm{~N} 2 \mathrm{~b}$ & M0 & 1 & LR 11 & - & 0 \\
\hline $\mathrm{F}$ & 49 & maxillary alveolus & IV & $\mathrm{T} 4$ & N0 & M0 & & HR 16 & + & 99 \\
\hline M & 51 & floor of mouth & III & $\mathrm{T} 2$ & N1 & M0 & 2 & pHR 26 & - & 0 \\
\hline M & 49 & tongue & $\mathrm{I}$ & $\mathrm{T} 1$ & No & M0 & 3 & HR 16 & - & 0 \\
\hline
\end{tabular}


In five patients, it was impossible to evaluate $\mathrm{p} 16$ due to technical reasons.

Table 1 also summarizes the association between HPV-positive/negative patients and p16-positive/negative patients; the correlation was at the threshold of statistical significance $(P=0.07401)$.

One interesting fact is that the HPV-positive patients were not predominantly p16-positive; to the contrary, only two HPV patients were p16-positive (LR 11 and HR16) (Table 2).

\section{TNM classifications and HPV}

The TNM system is the most widely used cancer staging system (in this case 7 th edition). Tumour size in $34 \%$ $(n=27)$ of the patients was at T2 stage. The next most frequent stage was T4, observed in 26 patients (33\%), followed by T3 in 19 patients (24\%), and six tumours were
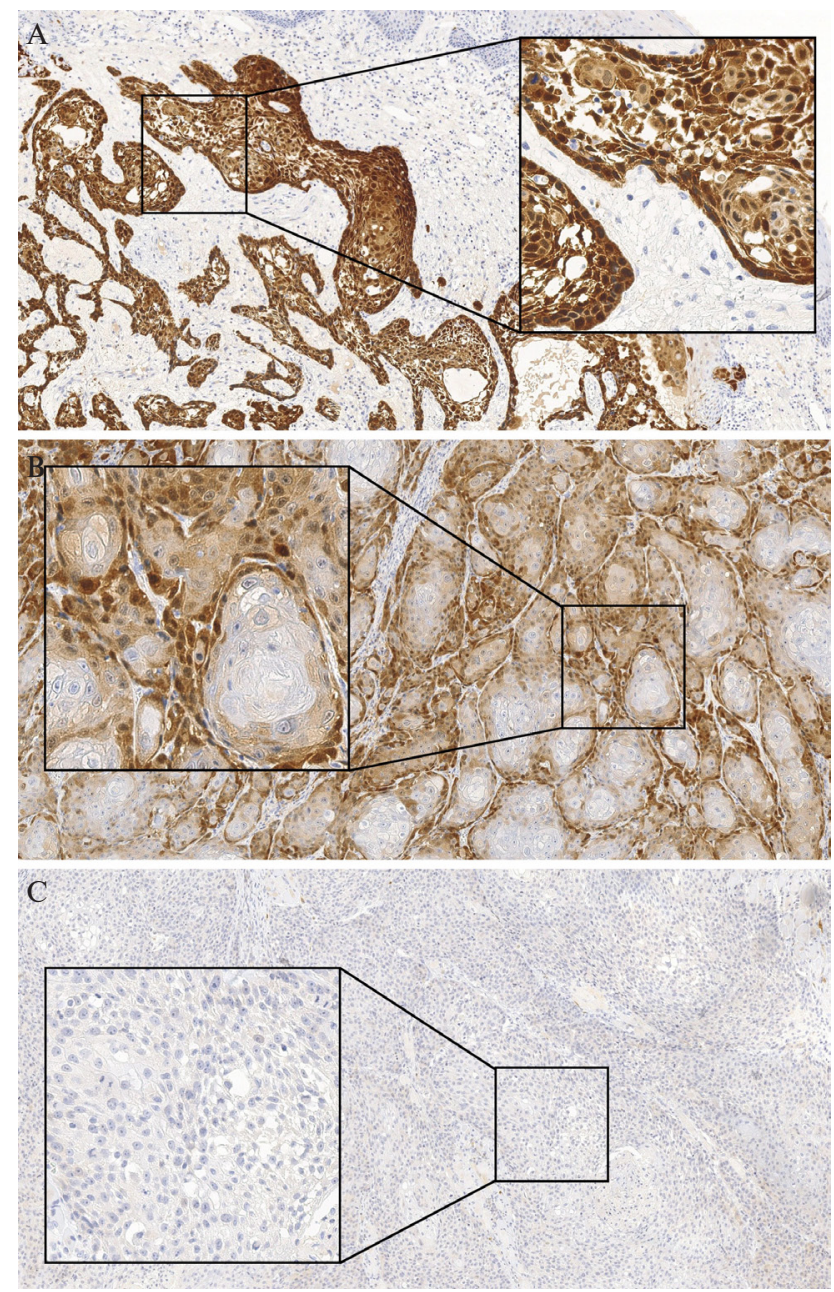

Fig. 1. Immunohistochemical staining of $\mathrm{p} 16$.

A Positive sample. In the detail of the image, there is surface squamous $\mathrm{p}-16$ negative epithelium, undergrown by $\mathrm{p} 16$ positive non-keratizing oral squamous cell carcinoma.

B: Partially positive sample. Nest of squamous cell carcinomas with segmentally indicated partial keratinization, bases of nests are p16 positive, central parts of nests $\mathrm{p} 16$ negative.

$\mathrm{C}$ : Negative sample. Oral squamous cell carcinoma nests, p16 completely negative. in T1 stage ( $8 \%)$. There was no significant difference between the HPV-positive and HVP-negative patients for the T stages $(P=0.73478)$. Regarding the lymph node metastases (N), 34 tumours were in N0 stage (43\%), 15 tumours were in N1 stage (19\%) and 29 tumours were in N2 stage (37\%); no patients were classified as N3 stage. There was no significant difference between the HPV-positive and HVP-negative patients in the $\mathrm{N}$ stage $(P=0.56)$. Regarding distant metastases $(\mathrm{M}), 75$ patients with tumours were at M0 stage (95\%) and three patients were at M1 stage (5\%). There was no significant difference between the HPV-positive and HPV-negative patients for the M stage $(P=0.60)$.

\section{Staging and HPV}

While comparing the advanced clinical stages III + IV to low stages I + II in relation to the presence of HPV, we observed a non-significant relationship as well $(P=0.53)$

\section{Grading and HPV}

Finally, we compared the rate of cell differentiation in relation to HPV positivity. Most tumours were very well differentiated (24-30\%) or moderately differentiated (31-39\%); only 13 patients had tumours with poor differentiation (16\%), and in one case, there was no differentiation at all. There was no significant difference between the HPV-positive and HPV-negative patients in grading $(P=0.95367)$.

\section{Univariate survival analysis}

Next, the prognostic significance of p16 and HPV was analysed using a log-rank test. In this analysis, the effect of HPV on the overall survival rate of patients was not demonstrated ( $P=0.78$ ). Accordingly, there was no effect in HPV status on the time to progression $(P=0.83749)$. P16 positivity was not found to have any effect on the overall survival rate of patients $(P=0.40798)$. There was no effect on p16-positive patients relative to the time to progression $(P=0.66329)$, see Fig 2 .

\section{Multivariate survival analysis}

In the next step, HPV and p16 status was analysed using a stepwise Cox proportional hazards model with HPV status, p16, clinical stage, grade, cT and $\mathrm{pN}$ as independent predictors. First, the overall survival rate was analysed. It was found that the only factor predicting the overall survival rate was the tumour grade, hazard ratio, $\mathrm{HR}=3.37,95 \%$ confidence interval, $\mathrm{CI} 1.33$ to $8.38, P=$ 0.01 . Next, the aim was to analyse the progression-free survival rate using multivariate analysis with a similar approach. Unfortunately, due to the limited number of cases, it was not possible to perform this analysis.

\section{DISCUSSION}

Many recent studies have pointed out the increasing prevalence of the human papilloma virus in the area of head and neck squamous cell carcinomas. Chatuverdi et al. ${ }^{23}$ studied changes in the incidence of oropharyngeal, 
A
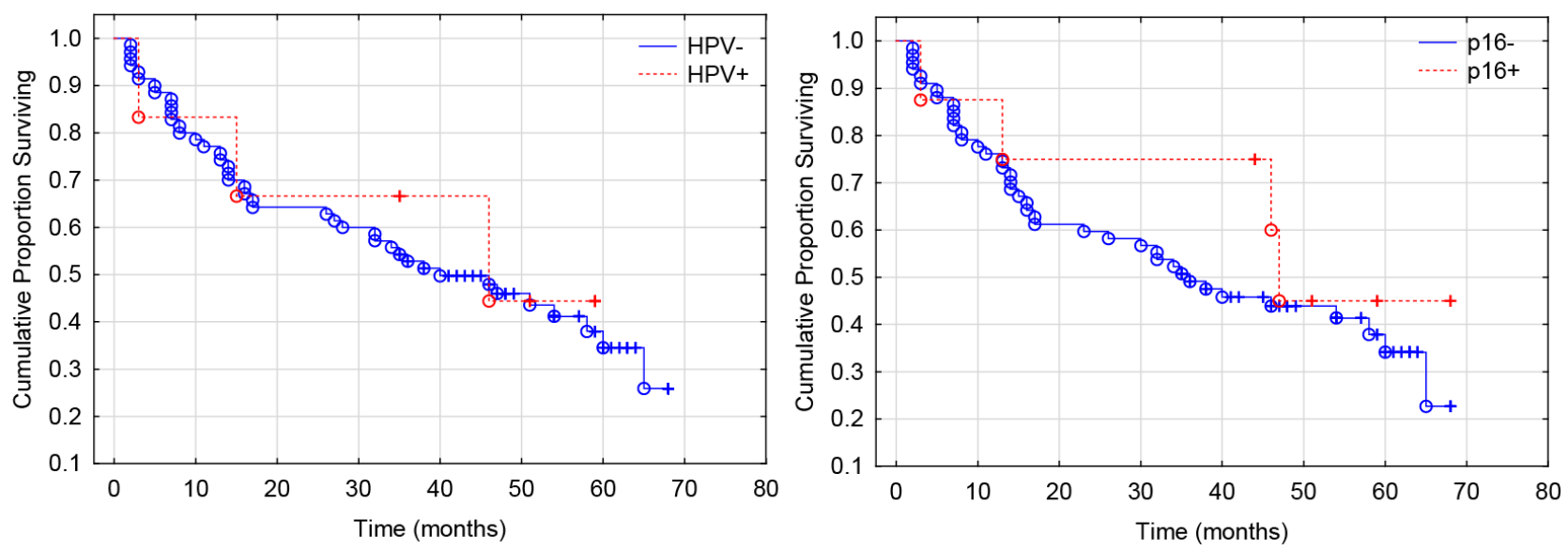

B
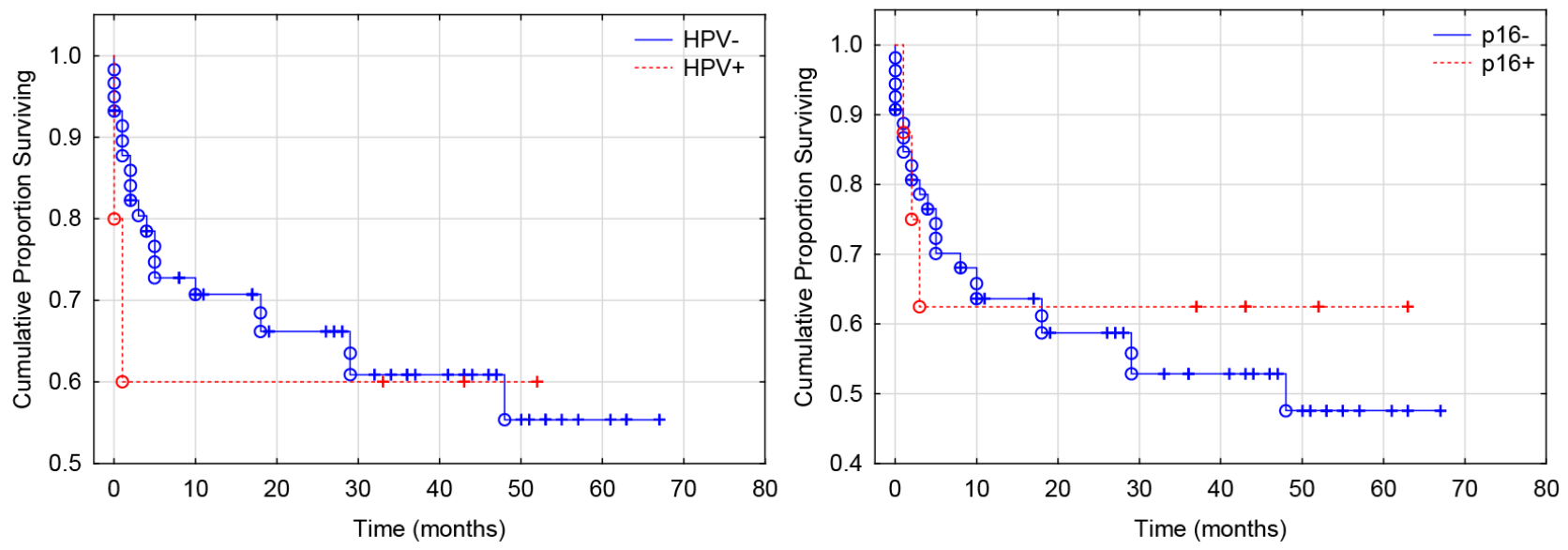

Fig. 2. Kaplan-Meier analysis, the effect of HPV status and p16 status on the overall survival rate (A) and the disease-specific survival rate.

oral cavity and lung cancers in both women and men, but only in oropharyngeal tumours was there an evident increase of incidences. This fact confirms the effect of HPV on the growing frequency of oropharyngeal tumours in the younger population. Our study confirmed HPV positivity in $8 \%$ of patients with OSCC. One of many systematic works reports that $26 \%$ of HNSCCs, when using the PCR method, yields HPV positivity. However, the high HPV positivity applies more to OPSCC than to OSCC (ref. ${ }^{3}$ ). Furthermore, many studies, if they consider OSCCs, include the base of tongue and pharynx cancers ${ }^{4,24,25}$ and occasionally the larynx and oral cavity ${ }^{26}$. Very rarely can we find a study regarding OSCC solely within the oral cavity, as it should correctly be, i.e. the specifically defined area from the line of lips (which are not included due to entirely different behaviour of the tumour) to the glossopalatine arches. Our study respected this delimitation, therefore we included only patients with OSCC, and not those with OPSCC. Moreover, the prevalence of HPV infection in the oral cavity is quite varied, depending on the applied laboratory method, the size of the study group, race and geographical location. The prevalence of these cancers is lesser in Asia, where it can be influenced by either culturally acceptable or discouraged forms of sexual behaviou $^{27,28}$. Some studies analyzing HPV subtypes with a high prevalence also include verrucous carcinomas in OSCCs $\left(\right.$ ref. $\left.^{29}\right)$.

Studies that generally focus on head and neck cancers without pinpointing their exact location, report a high range due to the HPV infection, from $32 \%$ to $84 \%$ (ref. ${ }^{17,30,31}$ ). When the location is limited to our area of interest, specifically the oral cavity, Syrjänen ${ }^{32}$ reports a $12 \%$ prevalence, Koppikar a $6 \%$ prevalence ${ }^{33}$, Simonato 17\% (ref. ${ }^{34}$ ), Glombitza 17\% (ref. ${ }^{35}$ ), Van Monsjou 10\% (ref. ${ }^{36}$ ) and Koslabova $16.9 \%$ (ref. ${ }^{37}$ ). The average value most generally accepted is a $13 \%$ prevalence specifically in the oral cavity ${ }^{38}$, with the prevalence being higher in men than in women ${ }^{39-41}$. Furthermore, it was found that high-risk sexual behaviour, including orogenital sex, is one of the most probable means of transmission between the genitals and the oral cavity ${ }^{41,42}$.

Squamous cell carcinoma of the oral cavity is generally caused by the long-term impact of known risk factors, e.g. the use of tobacco and alcohol along with chronic traumatisation. Many studies imply that there is a possible impact of HPV infection on the head and neck tumours' 
carcinogenesis but the exact role of HPV infection in the oral cavity remains unclear. One reason is that there seems to be less interest in this clearly defined group.

Even if we respect the impact of HPV on the onset of OSCC, only a few studies designate it to be a definite prognostic factor in HPV-positive patients, although with a generally better therapeutic response $\mathrm{s}^{43-45}$. On the other hand, several studies reported worse results in HPV+ patients $^{46-48}$. Our work provides similar results, where HPV positivity did not have an impact on the overall survival rate of patients and time of progression, which is in accordance with other works ${ }^{34}$

Another fundamental factor of carcinogenesis in relation to HPV is its subtype, where only HR types should be responsible for the onset of cancer, with the most commonly cited types being 16, 18 and 33 in the head and neck area ${ }^{17,37,49-50}$. In OSCC, type 16 is considered to be less common than in OPSCC (ref. ${ }^{51,52}$ ). High-risk types 31,33 and others are rarely observed ${ }^{53,54}$, which, unlike the LR types (e.g. LR 11), are most often detected in recurrent respiratory papillomatosis ${ }^{55}$ and only marginally correspond with larynx carcinogenesis. Incidentally, the presence of LR 11 was confirmed in one of our patients, and this sample was repeatedly tested immunohistochemically, proving a high expression of protein p16 of over $85 \%$. This indicates that there was only the presence of the HPV infection and not the carcinogenesis cause. This agrees with the summarizing work of Syrjänen, in which the viral DNA was PCR-detected both in the cancer-altered and the normal oral cavity epithelium ${ }^{56}$.

There is still insufficient agreement on what method for routine use is the most suitable for identifying HPV within the tumour tissue ${ }^{20,57}$. The combination of protein p16 immunohistochemistry and the PCR DNA-based method seems to be the most convenient because it yields both high specificity and sensitivity ${ }^{58}$. In our study, we employed both recommended methods and discovered that remarkably, many p16-marked tumours that did not yield positivity had none of the 28 tested HPV genotypes. Furthermore, HPV positivity was determined from samples in which, consequently, there was a clearly confirmed presence of squamous cell carcinoma. Five patients with a high p16 expression rate were HPV-negative for one of the 28 standardized types. Similar results were reported by Reusenbach et al. ${ }^{59}$, where most OSCC samples were p16-negative. Furthermore, in 6 out of 17 of the strongly positive p 16 tumours, HPV negativity was observed. Upile et al. focused on the occurrence of HPV in nonoropharyngeal carcinomas, where out of 102 patients with OSCC, 8 patients were p16-positive but only 4 patients were HPV-positive ${ }^{60}$. Kouketsu et al. in their work reported HPV positivity in 13 out of the 26 p16-positive patients in total. The remaining 11 patients with a high p16 expression rate were HPV-negative ${ }^{61}$. Van Monsjou et al., using the same method, identified 13 p16-positive patients out of 14-HPV positive patients. On the other hand, in 5 p16-positive patients, HPV negativity was observed ${ }^{36}$. This group could possibly have included a combination of HPV-positive patients having a false negative result along with HPV-negative patients, in whom the molecular mechanism resulted in an increased p 16 expression due to HPV negativity. This may be explained by either somatic mutations of retinoblastoma signalling pathways ( $\mathrm{pRb})$, or carcinogenesis caused by other means rather than by a present standardized HPV subtype ${ }^{62}$. Another possible explanation for this difference could be the result of a biological and anatomical heterogeneity between these sites. Large tumours in the retromolar trigone, for example, may be indiscernible from tumours from the palatine tonsils due to the anatomical nearness of these sites, which would result in their incorrect categorization. Although it was rarely reported in the floor of the oral cavity, the HPV infection could result in the cancerous development within the ectopic tonsillar tissue ${ }^{63,64}$. In our set of p16-positive patients, there was a greater prevalence in the floor of the oral cavity (4/8), followed by the cheek $(2 / 8)$, then the tongue and the maxillary alveolus in one patient each. Lim et al. ${ }^{65}$, in their recent study, narrowed the area of interest in the oral cavity to just the tongue and evaluated CDKN2A (p16) aberrations. However, unlike our work, they did not observe any significant correlation with clinical characteristics. Similarly, the results obtained by Kouketsu et al. indicate a positive correlation between p16 positivity and the overall survival rate, even though this relationship was not considered to be significant ${ }^{61}$. These results imply that every anatomical sub-part requires an independent evaluation with a larger set of patients to exactly define the prognostic role of the $\mathrm{p} 16$ expression. Thus, our results should be interpreted carefully because of the small sets of patients corresponding to each particular location of the oral cavity.

\section{CONCLUSION}

P16INK4 immunohistochemistry is an exact and a generally-available tool in the prognostic and predictive characterization of squamous cell cancers in the head and neck. This study focuses on the relationship between HPV and p16 prognosis in OSCC. No causality between p16, OS and PFS was proved in OSCC. The low prevalence of HPV infection ( $8 \%$ ) in our study group indicates its small role in the carcinogenesis of the oral cavity. However, to confirm these conclusions, studies with larger sets of patients will be needed.

Author contributions: JB: literature search, data analysis and manuscript writing; JZ, JG: data analysis, manuscript writing; JB, CM, ZD, OB: final approval, critical reading and manuscript revision.

Conflict of interest statement: There are no conflicts of interest.

\section{REFERENCES}

\footnotetext{
1. Precht $C$, Baustian S, Tribius $S$, Schöllchen $M$, Hanken $H$, Smeets $R$, Heiland M, Gröbe A. The benefit of abdominal sonography and chest $X$-ray for staging oral squamous cell carcinomas in stages UICC I and II. J Cranio-Maxillofac Surg 2016;44(2):186-90.
} 
2. SVOD. http://svod.cz/?sec=analyzy. Accessed March 31, 2018.

3. Kreimer AR, Clifford GM, Boyle P, Franceschi S. Human papillomavirus types in head and neck squamous cell carcinomas worldwide: a systematic review. Cancer Epidemiol Biomarkers Prev 2005;14(2):46775.

4. Gillison ML. Human papillomavirus-associated head and neck cancer is a distinct epidemiologic, clinical, and molecular entity. Semin Oncol 2004;31(6):744-54.

5. Gillison ML, D'Souza G, Westra W, Sugar E, Xiao W, Begum S, Viscidi R. Distinct risk factor profiles for human papillomavirus type 16-positive and human papillomavirus type 16-negative head and neck cancers. J Natl Cancer Inst 2008;100(6):407-20.

6. Applebaum KM, Furniss CS, Zeka A, Posner MR, Smith JF, Bryan J, Eisen EA, Peters ES, McClean MD, Kelsey KT. Lack of Association of Alcohol and Tobacco with HPV16-Associated Head and Neck Cancer. JNCI J Natl Cancer Inst 2007;99(23):1801-10.

7. Bzhalava D, Eklund C, Dillner J. International standardization and classification of human papillomavirus types. Virology 2015;476:3414.

8. Duensing S, Münger K. Mechanisms of genomic instability in human cancer: insights from studies with human papillomavirus oncoproteins Int J Cancer 2004;109(2):157-62.

9. Muñoz N, Bosch FX, de Sanjosé S, Herrero R, Castellsagué X, Shah KV, Snijders PJF, Meijer CJLM, International Agency for Research on Cancer Multicenter Cervical Cancer Study Group. Epidemiologic classification of human papillomavirus types associated with cervical cancer. N Engl J Med 2003;348(6):518-27.

10. Mydlarz WK, Hennessey PT, Califano JA. Advances and Perspectives in the Molecular Diagnosis of Head and Neck Cancer. Expert Opin Med Diagn 2010;4(1):53-65.

11. Gillison ML. HPV and prognosis for patients with oropharynx cancer. Eur J Cancer 2009;45 Suppl 1:383-5.

12. Zhang HS, Postigo AA, Dean DC. Active transcriptional repression by the Rb-E2F complex mediates G1 arrest triggered by p16INK4a, TGFbeta, and contact inhibition. Cell 1999;97(1):53-61.

13. Namazie A, Alavi S, Olopade Ol, Pauletti G, Aghamohammadi N, Aghamohammadi M, Gornbein JA, Calcaterra TC, Slamon DJ, Wang MB, Srivatsan ES. Cyclin D1 amplification and p16(MTS1/CDK4I) deletion correlate with poor prognosis in head and neck tumors. Laryngoscope 2002;112(3):472-81.

14. Weinberger PM, Merkley MA, Khichi SS, Lee JR, Psyrri A, Jackson LL, Dynan WS. Human papillomavirus-active head and neck cancer and ethnic health disparities. Laryngoscope 2010;120(8):1531-7.

15. Stephen JK, Divine G, Chen KM, Chitale D, Havard S, Worsham MJ. Significance of $p 16$ in site-specific HPV positive and HPV negative HNSCC. Cancer Clin Oncol 2013;2(1):51-61.

16. Fakhry C, Westra WH, Li S, Cmelak A, Ridge JA, Pinto H, Forastiere A, Gillison ML. Improved Survival of Patients With Human Papillomavirus-Positive Head and Neck Squamous Cell Carcinoma in a Prospective Clinical Trial. J Natl Cancer Inst 2008;100(4):261-9.

17. Lassen P, Eriksen JG, Hamilton-Dutoit S, Tramm T, Alsner J, Overgaard J. Effect of HPV-associated p16INK4A expression on response to radiotherapy and survival in squamous cell carcinoma of the head and neck. J Clin Oncol 2009;27(12):1992-8.

18. Psyrri A, Prezas L, Burtness B. Oropharyngeal cancer. Clin Adv Hematol Oncol HO 2008;6(8):604-12.

19. Ang KK, Harris J, Wheeler R, Weber R, Rosenthal DI, Nguyen-Tân PF, Westra WH, Chung CH, Jordan RC, Lu C. Human papillomavirus and survival of patients with oropharyngeal cancer. N Engl J Med 2010;363(1):24-35.

20. Rischin D, Young RJ, Fisher R, Fox SB, Le Q-T, Peters LJ, Solomon B, Choi J, O'Sullivan B, Kenny LM, McArthur GA. Prognostic significance of p16INK4A and human papillomavirus in patients with oropharyngeal cancer treated on TROG 02.02 phase III trial. J Clin Oncol 2010;28(27):4142-8.

21. Jordan RC, Lingen MW, Perez-Ordonez B, He X, Pickard R, Koluder M, Jiang B, Wakely P, Xiao W, Gillison ML. Validation of methods for oropharyngeal cancer HPV status determination in US cooperative group trials. Am J Surg Pathol 2012;36(7):945-54.

22. Shi W, Kato H, Perez-Ordonez B, Pintilie M, Huang S, Hui A, O'Sullivan B, Waldron J, Cummings B, Kim J, Ringash J, Dawson LA, Gullane P, Siu L, Gillison M, Liu F-F. Comparative prognostic value of HPV16 E6 mRNA compared with in situ hybridization for human oropharyngeal squamous carcinoma. J Clin Oncol 2009;27(36):6213-21.
23. Chaturvedi AK, Anderson WF, Lortet-Tieulent J, Curado MP, Ferlay J, Franceschi S, Rosenberg PS, Bray F, Gillison ML. Worldwide trends in incidence rates for oral cavity and oropharyngeal cancers. J Clin Oncol 2013;31(36):4550-9.

24. Pannone G, Santoro A, Papagerakis S, Lo Muzio L, De Rosa G, Bufo P. The role of human papillomavirus in the pathogenesis of head \& neck squamous cell carcinoma: an overview. Infect Agent Cancer 2011;6:4.

25. Andrews E, Seaman WT, Webster-Cyriaque J. Oropharyngeal carcinoma in non-smokers and non-drinkers: a role for HPV. Oral Oncol 2009;45(6):486-91.

26. Krüger M, Pabst AM, Walter C, Sagheb K, Günther C, Blatt S, Weise $\mathrm{K}$, Al-Nawas B, Ziebart T. The prevalence of human papilloma virus (HPV) infections in oral squamous cell carcinomas: a retrospective analysis of 88 patients and literature overview. J Craniomaxillofac Surg 2014;42(7):1506-14.

27. Li W, Tran N, Lee SC, O'Brien CJ, Tse GM, Scolyer RA, Hong A, Milross $\mathrm{C}, \mathrm{Yu} \mathrm{KH}$, Rose BR. New evidence for geographic variation in the role of human papillomavirus in tonsillar carcinogenesis. Pathology 2007;39(2):217-22.

28. Chien C-Y, Su C-Y, Fang F-M, Huang H-Y, Chuang H-C, Chen C-M, Huang C-C. Lower prevalence but favorable survival for human papillomavirus-related squamous cell carcinoma of tonsil in Taiwan. Oral Oncol 2008;44(2):174-9.

29. González JV, Gutiérrez RA, Keszler A, Colacino M del C, Alonio LV, Teyssie AR, Picconi MA. Human papillomavirus in oral lesions. Medicina (Mex). 2007;67(4):363-8.

30. Blomberg M, Nielsen A, Munk C, Kjaer SK. Trends in head and neck cancer incidence in Denmark, 1978-2007: focus on human papillomavirus associated sites. Int J Cancer 2011;129(3):733-41.

31. Ang KK, Sturgis EM. Human papillomavirus as a marker of the natural history and response to therapy of head and neck squamous cell carcinoma. Semin Radiat Oncol 2012;22(2):128-42.

32. Syrjänen SM, Syrjänen KJ, Happonen RP. Human papillomavirus (HPV) DNA sequences in oral precancerous lesions and squamous cell carcinoma demonstrated by in situ hybridization. J Oral Pathol 1988;17(6):273-8.

33. Koppikar P, deVilliers E-M, Mulherkar R. Identification of human papillomaviruses in tumors of the oral cavity in an Indian community. Int J Cancer 2005;113(6):946-50.

34. Simonato LE, Garcia JF, Sundefeld MLMM, Mattar NJ, Veronese LA, Miyahara GI. Detection of HPV in mouth floor squamous cell carcinoma and its correlation with clinicopathologic variables, risk factors and survival. J Oral Pathol Med 37(10):593-8.

35. Glombitza F, Guntinas-Lichius O, Petersen I. HPV status in head and neck tumors. Pathol - Res Pract 2010;206(4):229-34.

36. van Monsjou HS, van Velthuysen MLF, van den Brekel MWM, Jordanova ES, Melief CJM, Balm AJM. Human papillomavirus status in young patients with head and neck squamous cell carcinoma. Int J Cancer 2012;130(8):1806-12.

37. Koslabova E, Hamsikova E, Salakova M, Klozar J, Foltynova E, Salkova E, Rotnaglova E, Ludvikova V, Tachezy R. Markers of HPV infection and survival in patients with head and neck tumors: Markers of HPV infection. Int J Cancer 2013;133(8):1832-9.

38. Laco J, Vosmikova H, Novakova V, Celakovsky P, Dolezalova H, Tucek L, Nekvindova J, Vosmik M, Cermakova E, Ryska A. The role of highrisk human papillomavirus infection in oral and oropharyngeal squamous cell carcinoma in non-smoking and non-drinking patients: a clinicopathological and molecular study of 46 cases. Virchows Arch Int J Pathol 2011;458(2):179-87.

39. Kero K, Rautava J, Syrjänen K, Grenman S, Syrjänen S. Oral mucosa as a reservoir of human papillomavirus: point prevalence, genotype distribution, and incident infections among males in a 7-year prospective study. Eur Urol 2012;62(6):1063-70.

40. Gillison ML, Broutian T, Pickard RKL, Tong Z, Xiao W, Kahle L, Graubard $\mathrm{BI}$, Chaturvedi AK. Prevalence of oral HPV infection in the United States, 2009-2010. JAMA 2012;307(7):693-703.

41. Pickard RKL, Xiao W, Broutian TR, He X, Gillison ML. The prevalence and incidence of oral human papillomavirus infection among young men and women, aged 18-30 years. Sex Transm Dis 2012;39(7):55966.

42. Chung $\mathrm{CH}$, Bagheri A, D'Souza G. Epidemiology of oral human papillomavirus infection. Oral Oncol 2014;50(5):364-9.

43. D'Souza G, Agrawal Y, Halpern J, Bodison S, Gillison ML. Oral sexual 
behaviors associated with prevalent oral human papillomavirus infection. J Infect Dis 2009;199(9):1263-9.

44. Schwartz SR, Yueh B, McDougall JK, Daling JR, Schwartz SM. Human papillomavirus infection and survival in oral squamous cell cancer: a population-based study. Otolaryngol Head Neck Surg 2001;125(1):19.

45. Elango KJ, Suresh A, Erode EM, Subhadradevi L, Ravindran HK lyer SK, lyer SKR, Kuriakose MA. Role of human papilloma virus in oral tongue squamous cell carcinoma. Asian Pac J Cancer Prev 2011;12(4):889-96.

46. Kozomara R, Jović N, Magić Z, Branković-Magić M, Minić V. p53 mutations and human papillomavirus infection in oral squamous cel carcinomas: correlation with overall survival. J Craniomaxillofac Surg 2005;33(5):342-8.

47. Duray A, Descamps G, Decaestecker C, Remmelink M, Sirtaine N, Lechien J, Ernoux-Neufcoeur P, Bletard N, Somja J, Depuydt CE, Delvenne P, Saussez S. Human papillomavirus DNA strongly correlates with a poorer prognosis in oral cavity carcinoma. Laryngoscope 2012;122(7):1558-65.

48. Lee LA, Huang CG, Liao CT, Lee LY, Hsueh C, Chen TC, Lin CY, Fan $\mathrm{KH}$, Wang HM, Huang SF, Chen IH, Kang CJ, Ng SH, Yang SL, Tsao KC, Chang YL, Yen TC. Human papillomavirus-16 infection in advanced oral cavity cancer patients is related to an increased risk of distant metastases and poor survival. PloS One 2012;7(7):e40767.

49. Woodman CBJ, Collins SI, Young LS. The natural history of cervical HPV infection: unresolved issues. Nat Rev Cancer 2007;7(1):11-22.

50. Chen X, Sturgis EM, El-Naggar AK, Wei Q, Li G. Combined effects of the p53 codon 72 and p73 G4C14-to-A4T14 polymorphisms on the risk of HPV16-associated oral cancer in never-smokers. Carcinogenesis 2008;29(11):2120-5.

51. Ha PK, Pai SI, Westra WH, Gillison ML, Tong BC, Sidransky D, Califano JA. Real-time quantitative PCR demonstrates low prevalence of human papillomavirus type 16 in premalignant and malignant lesions of the oral cavity. Clin Cancer Res 2002;8(5):1203-9.

52. Völter C, He Y, Delius H, Roy-Burman A, Greenspan JS, Greenspan D de Villiers EM. Novel HPV types present in oral papillomatous lesions from patients with HIV infection. Int J Cancer 1996 16;66(4):453-6.

53. Isayeva T, Li Y, Maswahu D, Brandwein-Gensler M. Human papillomavirus in non-oropharyngeal head and neck cancers: a systematic literature review. Head Neck Pathol 2012;6 Suppl 1:S104-20.

54. Lingen MW, Xiao W, Schmitt A, Jiang B, Pickard R, Kreinbrink P, PerezOrdonez B, Jordan RC, Gillison ML. Low etiologic fraction for highrisk human papillomavirus in oral cavity squamous cell carcinomas. Oral Oncol 2013;49(1):1-8.
55. Larson DA, Derkay CS. Epidemiology of recurrent respiratory papillomatosis. Acta Pathol Microbiol Immunol Scand 2010;118(6-7):45-4.

56. Syrjänen S, Lodi G, von Bültzingslöwen I, Aliko A, Arduino P, Campisi G, Challacombe S, Ficarra G, Flaitz C, Zhou HM, Maeda H, Miller C, Jontell M. Human papillomaviruses in oral carcinoma and oral potentially malignant disorders: a systematic review. Oral Dis 2011;17 Suppl 1:58-72.

57. Dreyer JH, Hauck F, Oliveira-Silva M, Barros MHM, Niedobitek G. Detection of HPV infection in head and neck squamous cell carcinoma: a practical proposal. Virchows Arch Int J Pathol 2013;462(4):3819

58. Schache AG, Liloglou T, Risk JM, Filia A, Jones TM, Sheard J, Woolgar JA, Helliwell TR, Triantafyllou A, Robinson M, Sloan P, HarveyWoodworth C, Sisson D, Shaw RJ. Evaluation of human papilloma virus diagnostic testing in oropharyngeal squamous cell carcinoma: sensitivity, specificity, and prognostic discrimination. Clin Cancer Res 2011;17(19):6262-71.

59. Reuschenbach M, Kansy K, Garbe K, Vinokurova S, Flechtenmacher C, Toth C, Prigge E-S, Thiele OC, Reinert S, Hoffmann J, von Knebel Doeberitz M, Freier K. Lack of evidence of human papillomavirusinduced squamous cell carcinomas of the oral cavity in southern Germany. Oral Oncol 2013;49(9):937-42.

60. Upile NS, Shaw RJ, Jones TM, Goodyear P, Liloglou T, Risk JM, Boyd MT, Sheard J, Sloan P, Robinson M, Schache AG. Squamous cell carcinoma of the head and neck outside the oropharynx is rarely human papillomavirus related. Laryngoscope 2014;124(12):2739-44.

61. Kouketsu A, Sato I, Abe S, Oikawa M, Shimizu Y, Takahashi T, Kumamoto $\mathrm{H}$. Detection of human papillomavirus infection in oral squamous cell carcinoma: a cohort study of Japanese patients. J Oral Pathol Med 2016;45(8):565-72. doi: 10.1111/jop.12416

62. Brauswetter D, Birtalan E, Danos K, Kocsis A, Krenacs T, Timar J, Mihalyi R, Horcsik D, Polony G, Tamas L, Petak I. p16INK4 expression is of prognostic and predictive value in oropharyngeal cancers independent of human papillomavirus status: a Hungarian study. Eur Arch Otorhinolaryngol 2017;274(4):1959-65.

63. Patel K, Ariyaratnam S, Sloan P, Pemberton MN. Oral tonsils (ectopic oral tonsillar tissue). Dent Update 2004;31(5):291-2.

64. Mogi K. Ectopic tonsillar tissue in the mucosa of the floor of the mouth simulating a benign tumour Case report. Aust Dent J 1991;36(6):456-8.

65. Lim AM, Do H, Young RJ, Wong SQ, Angel C, Collins M, Takano EA, Corry J, Wiesenfeld D, Kleid S, Sigston E, Lyons B, Fox SB, Rischin D, Dobrovic A, Solomon B. Differential mechanisms of CDKN2A (p16) alteration in oral tongue squamous cell carcinomas and correlation with patient outcome. Int J Cancer 2014;135(4):887-95 